\title{
Reduced HDAC2 in skeletal muscle of COPD patients
}

\author{
Masako To ${ }^{1,3}$, Elisabeth B. Swallow², Kenich Akashi ${ }^{1}, K^{2}$ Kosuke Haruki ${ }^{3}$, S Amanda Natanek ${ }^{2,4}$, Michael I. Polkey ${ }^{2}$, \\ Kazuhiro Ito $^{1}$ and Peter J. Barnes ${ }^{1 *}$
}

\begin{abstract}
Background: Skeletal muscle weakness in chronic obstructive pulmonary disease (COPD) is an important predictor of poor prognosis, but the molecular mechanisms of muscle weakness in COPD have not been fully elucidated. The aim of this study was to investigate the role of histone deacetylases(HDAC) in skeletal muscle weakness in COPD.

Methods and results: Twelve COPD patients, 8 smokers without COPD (SM) and 4 healthy non-smokers (NS) were recruited to the study. HDAC2 protein expression in quadriceps muscle biopsies of COPD patients (HDAC2/ $\beta$-actin: $0.59 \pm 0.34)$ was significantly lower than that in SM $(1.9 \pm 1.1, p=0.0007)$ and NS $(1.2 \pm 0.7, p=0.029)$. HDAC2 protein in skeletal muscle was significantly correlated with forced expiratory volume in $1 \mathrm{~s} \%$ predicted (FEV $1 \%$ pred) $\left(r_{s}=0.53, p=0.008\right)$ and quadriceps maximum voluntary contraction force (MVC) $\left(r_{s}=0.42, p=0.029\right)$. HDAC5 protein in muscle biopsies of COPD patients (HDAC5/ $\beta$-actin: $0.44 \pm 0.26$ ) was also significantly lower than that in SM $(1.29 \pm 0.39, p=0.0001)$ and NS $(0.98 \pm 0.43, p=0.020)$. HDAC5 protein in muscle was significantly correlated with $\mathrm{FEV}_{1} \%$ pred $\left(\mathrm{r}_{\mathrm{s}}=0.64, p=0.0007\right)$ but not with MVC $\left(r_{s}=0.30, p=0.180\right)$. Nuclear factor-kappa B (NF-KB) DNA binding activity in muscle biopsies of COPD patients (10.1 \pm 7.4) was significantly higher than that in SM (3.9 \pm 7.3 , $p=0.020)$ and NS $\left(1.0 \pm 1.2, p=0.004\right.$ and significantly correlated with HDAC2 decrease $\left(r_{s}=-0.59, p=0.003\right)$ and $\operatorname{HDAC5}\left(r_{s}=0.050, p=0.012\right)$. HDAC2 knockdown by RNA interference in primary skeletal muscle cells caused an increase in NF-KB activity, NF-KB acetylation and basal tumour necrosis factor (TNF)-a production, as well as progressive cell death through apoptosis.

Conclusion: Skeletal muscle weakness in COPD may result from HDAC2 down-regulation in skeletal muscle via acetylation and activation of NF-KB. The restoration of HDAC2 levels might be a therapeutic target for improving skeletal muscle weakness in COPD.
\end{abstract}

Keywords: COPD, Skeletal muscle dysfunction, HDAC2, Nuclear factor-kappa B, Apoptosis

\section{Background}

Chronic obstructive pulmonary disease (COPD) is an increasing health problem and it is predicted to be the third most common cause of death worldwide by 2020 [1]. In COPD patients, skeletal muscle weakness is an extrapulmonary manifestation that markedly reduces their quality of life and survival. Quadriceps weakness [2-4] and a decrease in quadriceps endurance $[5,6]$ have been reported in patients with COPD. Skeletal muscle strength in COPD, measured by maximum voluntary contraction $(\mathrm{MVC})$, is lower in approximately a third of all COPD

\footnotetext{
* Correspondence: p.j.barnes@imperial.ac.uk

${ }^{1}$ Airway Disease Section, National Heart and Lung Institute, Imperial College, Dovehouse Street, London SW3 6LY, UK

Full list of author information is available at the end of the article
}

patients than in age-matched controls [7]. Quadriceps strength is a better predictor of mortality in COPD than $\mathrm{FEV}_{1}$ in patients with moderate to very severe lung function impairment [8].

Skeletal muscle in COPD shows cellular structural changes, including a reduction in type I fibres, fibre crosssectional area and capillary contacts to muscle fibres [9], several metabolic changes and activation of the proinflammatory transcription factor nuclear factor-kappa B (NF-kB) [10], mitochondrial dysfunction [11] and enhanced autophagy [12]. Recently, it was reported that the histone deacetylases (HDAC) 3 and HDAC4 might be associated with muscle dysfunction in COPD $[13,14]$. These reports were descriptive and failed to demonstrate the precise molecular relationship between HDAC reduction 
and muscle dysfunction. Furthermore, data suggesting the potential molecular mechanisms of depression of HDACs in COPD muscle were not shown. The precise molecular mechanisms of muscle weakness underlying COPD need to be elucidated.

HDAC are a family of enzymes that remove acetyl groups from amino acids, usually lysine residues, and modify inflammatory gene expression by regulating histone acetylation and chromatin structure as well as through non-histone protein acetylation. There are 11 isoforms of Type I and II HDACs [15]. We have previously shown that total HDAC activity is reduced in peripheral lung and alveolar macrophages from COPD patients, and that the reduction correlates with the degree of airflow limitation [16]. In particular, the protein levels and mRNA levels of HDAC2 and HDAC5 mRNA levels were reduced in peripheral lung obtained from COPD patients [16].

HDACs also target non-histone proteins, including transcription factors such as NF- $\mathrm{kB}$, and a reduction of HDAC induces hyperacetylation of NF- $\mathrm{kB}$. NF- $\mathrm{kB}$ is activated in lung epithelial cells and macrophages of COPD patients and regulates the increased expression of proinflammatory cytokines, such as tumour necrosis factor(TNF)- $\alpha$, interleukin(IL)-1 $\beta$ and IL-6, all of which are increased in COPD patients. NF- $\mathrm{kB}$ activity is critically regulated by post-translational modifications, including acetylation. Acetylation of the p65 component of NF- $\mathrm{kB}$ at lysine ${ }^{221}$ abolishes binding of p65 to inhibitor of NF- $\mathrm{kB}-\beta$ (IкB $\beta$ ) [17], whereas acetylation of p65 at lysine $e^{310}$ is necessary for transcriptional activation [17].

Based on our previous report that HDAC2 and HDAC5 levels were decreased in peripheral lung from COPD patients [16], we hypothesised that HDAC2 and/or 5 protein expression in skeletal muscle from COPD patients was also reduced and this reduction is associated with skeletal muscle weakness in COPD patients. The aim of this study was to explore the molecular mechanisms of muscle weakness in COPD patients using clinical samples and a skeletal muscle cell line. Understanding the molecular mechanisms of skeletal muscle weakness in COPD may lead to new therapeutic approaches to this disabling problem.

\section{Methods}

\section{Patient recruitment}

Patients and healthy subjects were recruited from the Outpatient Department of the Royal Brompton Hospital. COPD patients were diagnosed and classified using Global Initiative for Obstructive Lung Disease (GOLD) criteria [18]. Patients and controls were free of relevant comorbidities, such as neurological or cardiac disease, which might cause skeletal muscle weakness as were those with co-morbidities known to cause systemic inflammation; however circulating markers of inflammation were not measured. An exacerbation requiring a change in medical therapy in the preceding 12 weeks was also an exclusion criteria. Biopsies were obtained from two studies (Brompton, Harefield \&NHLI Ethics Committee, Ref 03148) and (North London REC 3, Ref 06/Q0410/54) and written informed consent was obtained from all subjects.

Skeletal muscle strength was evaluated using maximal voluntary contraction force (MVC). MVC is one of the methods to evaluate muscle weakness which is recognised and described in the recent ERS/ATS statement [11]. It is used routinely in our laboratory and as previously published articles [7].

\section{Skeletal muscle biopsy}

Percutaneous biopsy of the vastus lateralis was performed using the technique of Bergstrom [19] after subjects had rested for $20 \mathrm{~min}$, on a day without strenuous physical activity. Samples for mRNA and protein analysis were frozen in liquid nitrogen, prior to storing at $-80^{\circ} \mathrm{C}$.

\section{Protein extraction from skeletal muscle biopsies}

Frozen skeletal muscle biopsy specimens were crushed and ground in liquid nitrogen with a pestle and mortar. Whole cell extraction was performed using the Nuclear Extraction kit (Active Motif, Carlsbad, CA) according to the manufacturers' instructions with minor modification. The protein concentration of each sample was determined with Bradford Bio-Rad Protein Assay (Bio-Rad Laboratories, Hertford, UK) using bovine serum albumin as a standard.

\section{NF-KB DNA binding assay}

NF- $\kappa B$ DNA binding activity was measured using TransAM NFkB p65 Activation Assay kit (Active Motif) according to the manufacturers' protocol. A standard curve for relative activity was generated using a recombinant NF- $\mathrm{kB}$ p65 protein. The relative activity of the top standard was defined to be 100 and the relative activity of each sample determined using the standard curve. Results were standardized according to the protein content $(\mu \mathrm{g})$ in each sample determined as described above.

\section{Quantitative real-time polymerase chain reaction (qRT-PCR)}

Total ribonucleic acid (RNA) extraction, reverse transcription of total RNA and QRT-PCR were performed as previously shown [16]. The amount of target transcript in each sample was standardized against levels of GNB2L1.

\section{Gel electrophoresis and western blotting}

Whole cell extracts (30 $\mu \mathrm{L}$ each) were electrophoresed and protein samples in the gels were transferred to a nitrocellulose membrane as previously shown [16]. 
Immunoreactive bands of HDAC2, HDAC5 and $\beta$-actin were detected with anti-HDAC2 antibody (Santa Cruz Biotechnology, Santa Cruz, CA), anti-HDAC5 antibody (Santa Cruz Biotechnology) and anti- $\beta$ actin antibody (Abcam, Cambridge, UK), respectively. Band densities of HDAC2 and HDAC5 in each sample were normalized with that of the $\beta$-actin or glyceraldehyde 3 -phosphate dehydrogenase (GAPDH).

\section{RNA interference}

Primary normal human skeletal muscle cells were purchased from Lonza Walkersville Inc. (Walkersville, MD) and grown in Skeletal Muscle Cell Medium BulletKit $^{\mathrm{TM}}$. Cells were cultured in 6-well plates at a density of $1 \times 10^{6}$ cells/well, and transfected with 100nM of HDAC2 siRNA (Life Technologies) using PrimeFect ${ }^{\mathrm{TM}}$ siRNA transfection reagent (Lonza Walkersville Inc.) according to the manufacturers' instructions.

\section{Caspase 3 activity assay}

The activity of caspase- 3 was determined using a commercial Caspase-3 Colorimetric Assay Kit (BioVision Inc., Milpitas, CA). Fifty $\mu \mathrm{L}$ of chilled Cell Lysis Buffer was applied to each well of a 24-well plate, and cells were incubated on ice for $10 \mathrm{~min}$. After collection of cell lysis supernatant, the cell lysate $(100 \mu \mathrm{g}$ of protein) was added to $50 \mu \mathrm{l}$ Reaction Buffer followed by addition of the substrate for each sample and incubated at $37{ }^{\circ} \mathrm{C}$ for $1-2 \mathrm{~h}$. Colorimetric determination was performed by a microtiter plate reader.

\section{Statistical analysis}

Results were represented as mean \pm standard deviation of the mean. Multiple comparisons were performed by Kruskal-Wallis analysis, followed by post-test. Comparisons between two groups were performed with non-parametric Mann Whitney $U$-test. Correlation analysis was performed with Spearman's rank correlation coefficient. A $p$ value $<0.05$ was considered statistically significant. Analyses were performed using Graph Pad Prism 4 Software (Graph Pad Prism, San Diego, CA).

\section{Results}

\section{Subjects}

A total of 24 subjects (12 COPD patients aged $66 \pm 6$ years, 8 smokers without COPD (SM) aged $67 \pm 9$ years, and 4 healthy non-smokers (NS) aged $63 \pm 10$ years) were recruited for this study (Table 1 ). $\mathrm{FEV}_{1} \%$ predicted of COPD patients $(33 \pm 11 \%)$ showed significant airflow limitation compared to both NS $(104 \pm 15 \%)$ and SM $(107 \pm 20 \%)$.
Table 1 Patient Characteristics

\begin{tabular}{|c|c|c|c|}
\hline & $\begin{array}{l}\text { Non } \\
\text { smokers }\end{array}$ & $\begin{array}{l}\text { Smokers without } \\
\text { COPD }\end{array}$ & COPD \\
\hline $\mathrm{N}$ & 4 & 8 & 12 \\
\hline Age (yr) & $63 \pm 10$ & $67 \pm 9$ & $66 \pm 6$ \\
\hline $\operatorname{Sex}(F: M)$ & $1: 3$ & $2: 6$ & $0: 15$ \\
\hline $\begin{array}{l}\text { Smoking status } \\
\text { (current/ex/never) }\end{array}$ & $0 / 0 / 4$ & $2 / 6 / 0$ & $1 / 11 / 0$ \\
\hline Pack-year & $0 \pm 0$ & $16 \pm 22$ & $40 \pm 23$ \\
\hline BMI $\left(\mathrm{kg} / \mathrm{m}^{2}\right)$ & $23 \pm 2$ & $30 \pm 7$ & $25 \pm 5$ \\
\hline $\mathrm{FEV}_{1}(\mathrm{~L})$ & $3.00 \pm 0.91$ & $2.91 \pm 0.41$ & $1.05 \pm 0.37^{a, b}$ \\
\hline FEV (\%predicted) & $104 \pm 15$ & $107 \pm 20$ & $33 \pm 11^{a, b}$ \\
\hline RV \%predicted (\%) & ND & ND & $207 \pm 40$ \\
\hline KCO \%predicted (\%) & ND & ND & $52 \pm 19$ \\
\hline MVC (kg) & $40 \pm 19$ & $41 \pm 13$ & $34 \pm 10$ \\
\hline $\mathrm{PaO}_{2}(\mathrm{kPa})$ & ND & ND & $8.7 \pm 2.2$ \\
\hline Systemic Steroids & NA & NA & 0 \\
\hline ICS & NA & NA & 5 \\
\hline
\end{tabular}

Abbreviations: $B M I$ body mass index, $F E V_{1}$ forced expiratory volume in $1 \mathrm{~s}, R V$ residual volume, $K C O$ carbon monoxide transfer coefficient, $M V C$ maximum voluntary contraction, $\mathrm{PaO}_{2}$ partial pressure of oxygen in arterial blood, ICS inhaled corticosteroid, COPD chronic obstructive pulmonary disease, ND not determined, $N A$ not applicable

${ }^{\mathrm{a}} p<0.01$ compared to NS; ${ }^{\mathrm{b}} p<0.01$ compared to SM

One COPD patients were GOLD2, 4 patients GOLD3 and 7 patients GOLD4 category. Eleven out of 12 COPD patients were ex-smokers and only one patient was a current smoker, whereas 2 of 8 smokers without COPD were current smokers. Ten out of 12 COPD patients were treated with inhaled long-acting beta ${ }_{2}$-agonists. Two out of 12 COPD patients were treated with inhaled corticosteroids but none with systemic corticosteroids within 3 months of the study. One out of 12 COPD patients was treated with low dose oral theophylline.

\section{Expression of HDAC protein in skeletal muscle}

The level of HDAC2 protein in skeletal muscle of COPD patients (HDAC2/ $\beta$-actin ratio: $0.59 \pm 0.34$ ) was significantly lower than that SM $(1.9 \pm 1.1, p=0.0007)$ and NS $(1.2 \pm 0.7, p=0.029$; Fig. 1a). HDAC5 protein in skeletal muscle of COPD patients $(0.44 \pm 0.26)$ was also significantly lower than that of SM $(1.29 \pm 0.39, p=0.0001)$ and NS $(0.98 \pm 0.43, p=0.020$; Fig. 1b). In contrast, there were no significant differences in gene transcription levels (mRNA) of HDAC2 and HDAC5 in skeletal muscles among the 3 subject groups (Additional file 1: Figure S1).

\section{Associations between skeletal muscle HDAC expression and clinical parameters}

HDAC2 protein levels in skeletal muscle significantly correlated with both $\mathrm{FEV}_{1} \%$ predicted $\left(\mathrm{r}_{\mathrm{s}}=0.53, p=0.008\right.$; 

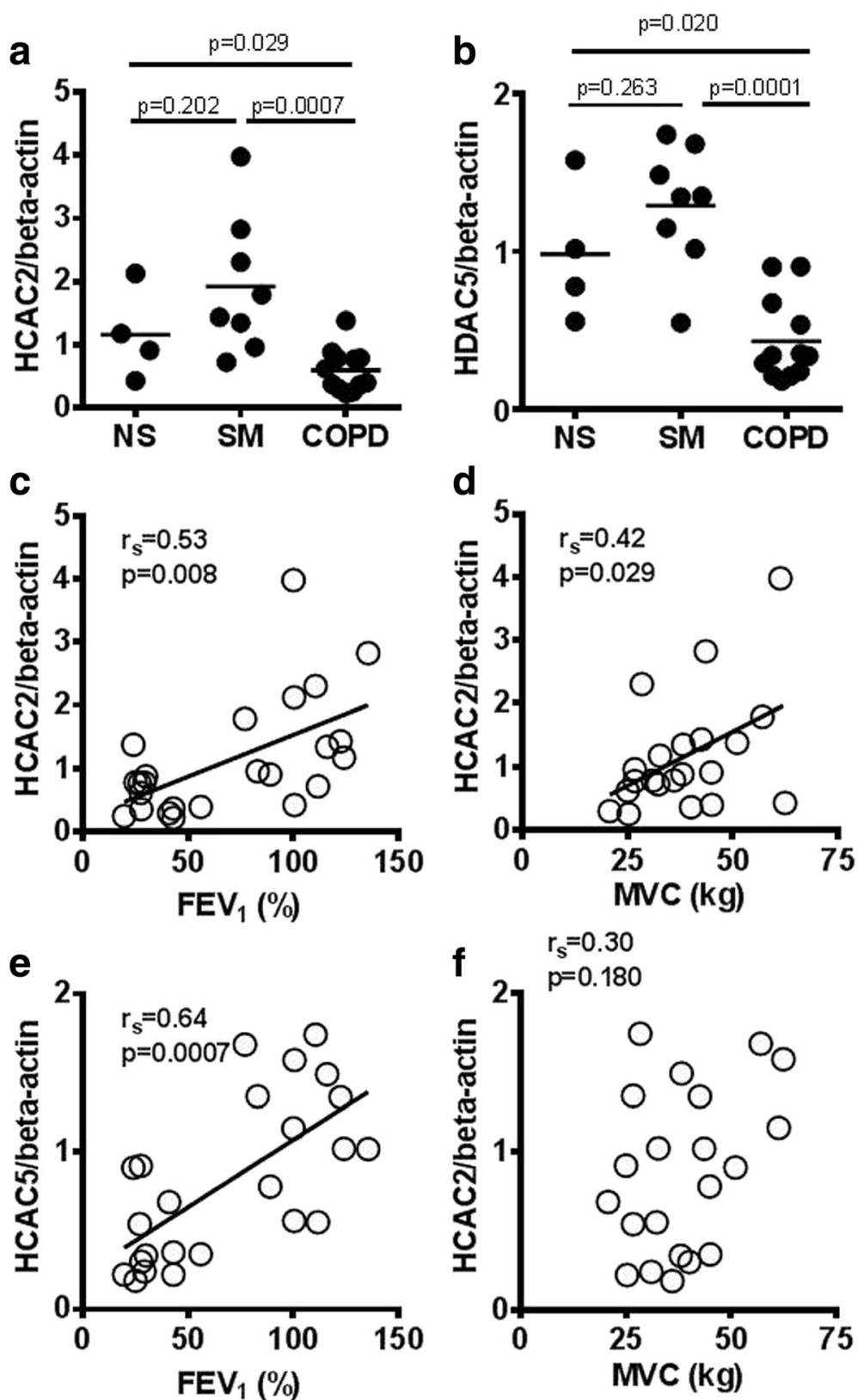

Fig. 1 HDACs in skeletal muscle biopsies and their correlations with clinical parameters. Whole cell proteins were extracted from quadriceps muscle biopsy specimens. HDAC2 protein (a) and HDAC5 protein (b) were measured by sodium dodecyl sulphate polyacrylamide gel electrophoresis/Western blot. Correlations between HDACs in skeletal muscle and clinical parameters were evaluated. FEV 1 \%predicted vs HDAC2 protein expression (c), MVC vs HDAC2 protein expression (d), FEV 1 \%predicted vs HDAC5 protein expression (e), MVC vs HDAC5 protein expression (f). Abbreviations: healthy non-smokers (NS), smokers without COPD (SM), chronic obstructive pulmonary disease (COPD), histone deacetylase $(H D A C)$, forced expiratory volume in $1 \mathrm{~s}\left(F E V_{1}\right)$; maximum voluntary contraction (MVC)

Fig. 1c) and quadriceps MVC ( $\mathrm{r}_{\mathrm{s}}=0.42, p=0.029$; Fig. 1d). HDAC5 protein in skeletal muscle correlated with $\mathrm{FEV}_{1} \%$ predicted $\left(r_{\mathrm{s}}=0.64, p=0.0007\right.$; Fig. 1e), whereas it did not correlate with MVC $\left(\mathrm{r}_{\mathrm{s}}=0.30, p=0.180\right.$; Fig. 1f). HDAC2 was also significantly correlated with $\mathrm{K}_{\mathrm{CO}} \%$ predicted $\left(\mathrm{r}_{\mathrm{s}}=\right.$ $0.67, p=0.027)$ and $\mathrm{TL}_{\mathrm{CO}} \%$ predicted $\left(\mathrm{r}_{\mathrm{s}}=0.50, p=0.044\right)$, whereas HDAC5 did not (Table 2).
NF-KB DNA binding activity in skeletal muscle

NF- $\mathrm{BB}$ DNA binding activity in skeletal muscle of COPD $(10.1 \pm 7.4$, (relative activity/ug protein)) was significantly higher than that of NS $(1.0 \pm 1.2, p=0.004)$ and SM $(3.9 \pm 7.3, p=0.020)$ (Fig. 2a). NF-кB DNA binding activity correlated negatively with $\mathrm{FEV}_{1} \%$ predicted $\left(\mathrm{r}_{\mathrm{s}}=-0.54, \quad p=0.007 ; \quad\right.$ Fig. $\left.2 \mathrm{~b}\right)$, positively with 
Table 2 Correlation between clinical parameters and HDAC2, HDAC5 and NF-kB DNA binding activity in all subjects

\begin{tabular}{|c|c|c|c|}
\hline & HDAC2 & HDAC5 & $N F-K B$ \\
\hline Age & 0.04 & -0.05 & 0.01 \\
\hline Pack-year & -0.28 & -0.35 & $0.62^{* *}$ \\
\hline BMI $\left(\mathrm{kg} / \mathrm{m}^{2}\right)$ & 0.36 & 0.04 & -0.03 \\
\hline $\mathrm{FEV}_{1} \%$ predicted & $0.53^{* *}$ & $0.64^{* *}$ & $-0.54^{* *}$ \\
\hline $\mathrm{FEV}_{1} / \mathrm{FVC} \%$ & $0.55^{* *}$ & $0.68^{* *}$ & $-0.53^{* *}$ \\
\hline RV \% predicted & -0.33 & -0.33 & $0.59^{*}$ \\
\hline KCO \% predicted & $0.67^{*}$ & 0.03 & $-0.74^{*}$ \\
\hline $\mathrm{TL}_{\mathrm{CO}} \%$ predicted & $0.50^{*}$ & 0.43 & $-0.81^{* *}$ \\
\hline $\mathrm{PaO}_{2}$ & 0.32 & 0.39 & $-0.54^{*}$ \\
\hline $\mathrm{PaCO}_{2}$ & -0.16 & -0.07 & 0.30 \\
\hline MVC & $0.42^{*}$ & 0.30 & $-0.50^{*}$ \\
\hline$N F-k B$ & $-0.59^{* *}$ & $-0.50^{*}$ & NA \\
\hline HDAC 2 protein & NA & $0.63^{* *}$ & $-0.59^{* *}$ \\
\hline HDAC5 protein & $0.63^{* *}$ & NA & $-0.50^{*}$ \\
\hline HDAC1 mRNA & -0.09 & -0.02 & 0.13 \\
\hline HDAC2 mRNA & 0.14 & -0.11 & -0.27 \\
\hline HDAC5 mRNA & -0.36 & -0.44 & 0.12 \\
\hline
\end{tabular}

Abbreviations: $B M I$ body mass index, $F E V$, forced expiratory volume in $1 \mathrm{~s}, R V$ residual volume, $K C O$ carbon monoxide transfer coefficient, $T L_{C O}$ transfer factor for carbon monoxide in the lung, $\mathrm{MVC}$ maximum voluntary contraction, $\mathrm{PaO}_{2}$ partial pressure of oxygen in arterial blood, NF-KB nuclear factor-kappa $B$ HDAC histone deacetylase, $N A$ not applicable

${ }^{*} p<0.05 ;{ }^{* *} p<0.01$

pack-years $\quad\left(\mathrm{r}_{\mathrm{s}}=0.62, \quad p=0.001 ; \quad\right.$ Fig. $\left.2 \mathrm{c}\right) \quad$ and negatively with MVC $\left(\mathrm{r}_{\mathrm{s}}=0.50, p=0.019\right.$; Fig. $\left.2 \mathrm{~d}\right)$. NF-kB DNA binding activity also correlated with $\mathrm{KCO} \%$ predicted $\left(\mathrm{r}_{\mathrm{s}}=-0.74, p=0.011\right)$, RV \% predicted $\left(\mathrm{r}_{\mathrm{s}}=0.58, p=0.023\right)$ and $\mathrm{TL}_{\mathrm{CO}} \%$ predicted $\left(\mathrm{r}_{\mathrm{s}}=-0.81, p=0.0002\right)$ (Table 2$)$. In addition, NF- $\mathrm{kB}$ DNA binding activity in skeletal muscle significantly correlated with HDAC2 protein expression $\left(\mathrm{r}_{\mathrm{s}}=-0.59, p=0.003\right.$, Fig. 2e) and HDAC5 protein expression $\left(\mathrm{r}_{\mathrm{s}}=-0.50, p=0.012\right.$, Fig. $\left.2 \mathrm{f}\right)$.

\section{HDAC2 knockdown induced NF-кB activation in skeletal muscle cells}

In primary skeletal muscle cells, transfection of HDAC2 siRNA induced a 73\% reduction in HDAC2 mRNA evaluated by RT-PCR (data not shown) and a $52 \%$ reduction in HDAC2 protein evaluated by Western blotting (Fig. 3a) at $24 \mathrm{~h}$ after transfection. The basal NF-kB activity in nuclear extracts $(40 \mu \mathrm{g})$ was significantly higher in HDAC2 knockdown cells than in negative control siRNA (SiNeg) transfected cells and nontransfected cells $(\mathrm{NT})$ : (SiHDAC2 $0.35 \pm 0.053 \mathrm{OD}$; NT $0.15 \pm 0.054$; SiNeg: $0.20 \pm 0.028, p<0.05, n=3$; Fig. 3b) The acetylation of $\mathrm{Lys}^{310}$ p65-NF-kB was also elevated in HDAC2 knockdown cells (ratio of acetylated p65/total p65: NT: $0.016 \pm 0.0041, \quad$ SiNeg: $0.17 \pm 0.00056$, SiHDAC2: $0.28 \pm 0.0043$ OD, $p<0.05, n=3$; Fig. $3 c)$. The basal level of TNF- $\alpha$ increased in the supernatants of HDAC2 knockdown cells, and TNF- $\alpha$ production was inhibited by SC514 $(20 \mu \mathrm{M})$, an IKK- $\beta$ inhibitor, when given $12 \mathrm{~h}$ after transfection (Fig. 3d). The skeletal muscle cell viability determined by methylthiazol tetrazolium (MTT) assay decreased over time after HDAC2 siRNA transfection, whereas SiNeg transfection did not affect viability (Fig. 3e). More importantly, the reduction in skeletal muscle cell viability seen $120 \mathrm{~h}$ after transfection was inhibited by treatment with the IKK- $\beta$ inhibitor. Skeletal muscle cell apoptosis evaluated by caspase 3 activity in HDAC2 knockdown cell (120 h after transfection) was also significantly higher than controls $(p<0.01$, Fig. 3f). The elevated apoptosis in HDAC2 knockdown cells were also attenuated by IKK inhibitor.

\section{Discussion}

In this study, we have demonstrated for the first time a reduction in HDAC2 protein in skeletal muscle from COPD patients, and this is of a similar order to the reduction in HDAC2 protein expression previously reported in peripheral lung tissue, alveolar macrophages, sputum macrophages, bronchial biopsies and peripheral blood mononuclear cells from COPD patients $[16,20]$. HDAC2 protein expression in skeletal muscle was correlated with lung function (Fig. 1c), as previously shown in peripheral lung [16], but more importantly HDAC2 protein levels also correlated well with quadriceps weakness as measured by MVC (Fig. 1d). This suggests that decreased HDAC2 may be involved in the skeletal muscle weakness seen in COPD patients. In fact, HDAC2 knockdown by RNA interference decreased the viability of skeletal muscle cells in vitro through induction of apoptosis, as shown in Fig. 3e and $\mathrm{f}$.

Oxidative stress resulting from cigarette smoke extracts, is likely to be a major cause of the reduction in HDAC2 [21, 22]. There is compelling evidence for increased oxidative stress in skeletal muscle of COPD patients and a relationship with muscle weakness. For example, lipid peroxidation and nitrotyrosine are increased in skeletal muscle of COPD patients [23] and muscle protein carbonylation as a result of oxidative stress is associated with quadriceps weakness in COPD [24]. Barreiro et al. also demonstrated a high level of oxidative stress in skeletal muscle in COPD (carbonylation of proteins), which is associated with muscle dysfunction [25]. Furthermore, treatment with an antioxidant ( $N$-acetyl cysteine) increases exercise endurance time compared to a placebo [26]. In addition, Rossman and colleagues demonstrated an association between systemic oxidative stress and skeletal muscle dysfunction in COPD patients and also showed that systemic infusion of ascorbate, an antioxidant, induced resistance to muscle fatigue in COPD patients [27]. Thus, systemic 

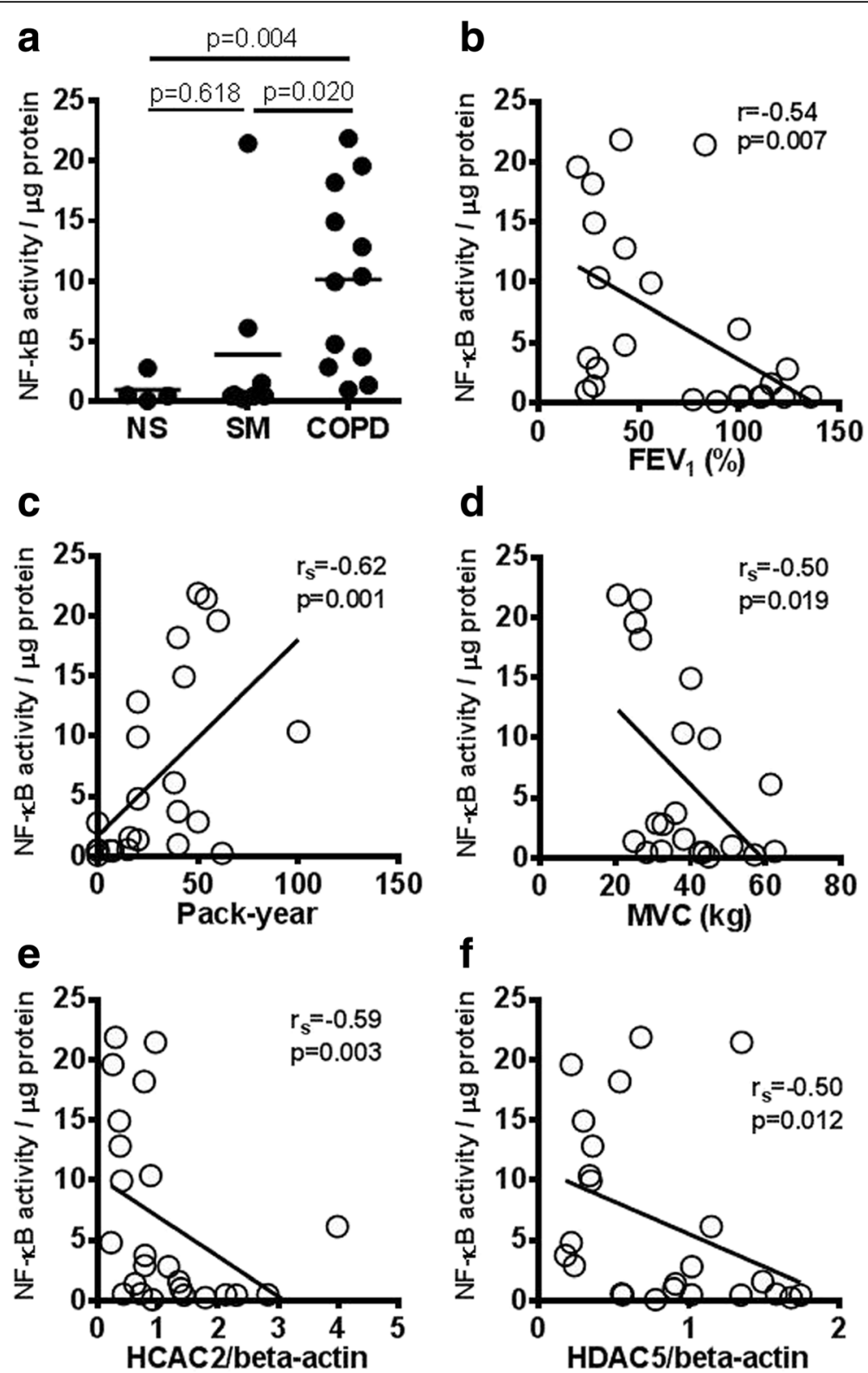

Fig. 2 NF-KB DNA binding activity in skeletal muscle biopsy specimens. a NF-KB DNA binding activity was measured in whole cell extracts from skeletal muscle biopsies. Correlation between NF-KB DNA binding activity and FEV ${ }_{1} \%$ predicted (b), cigarette exposure in pack-years (c). HDAC2 protein expression (d) and HDAC5 protein expression (e). Abbreviations: healthy non-smokers (NS), smokers without COPD (SM), chronic obstructive pulmonary disease (COPD), nuclear factor-kappa B (NF-KB), forced expiratory volume in $1 \mathrm{~s}\left(F E V_{1}\right)$, maximum voluntary contraction (MVC)

oxidative stress is associated with skeletal muscle dysfunction and the reduction of HDAC2 in skeletal muscle in COPD patients. Moreover, HDAC2 depletion is known to suppress nuclear factor erythroid 2-related factor (Nrf2), a redox-sensitive transcription factor that induces the expression of multiple anti-oxidant genes, resulting in impaired anti-oxidant defenses [28], and an increase in endogenous oxidative stress. Thus, HDAC2 repression and oxidative stress induction may enter into a vicious perpetuating circle.
NF- $k B$ DNA binding activity is significantly activated in skeletal muscle from COPD patients, as previously reported in a small study of cachectic COPD patients [10]. As NF- $\mathrm{kB}$ is an oxidative stress-sensitive transcription factor, increased oxidative stress in skeletal muscle might the cause of NF- $k B$ activation [29, 30]. In this study, we have also demonstrated a correlation between HDAC2 expression and NF-kB DNA binding activity in skeletal muscle cells (Fig. 2d). HDAC2 knockdown in primary skeletal muscle cells also increased NF- $\kappa B$ DNA binding 


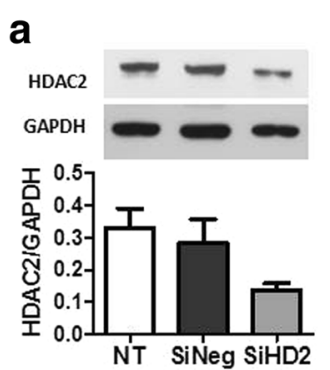

d

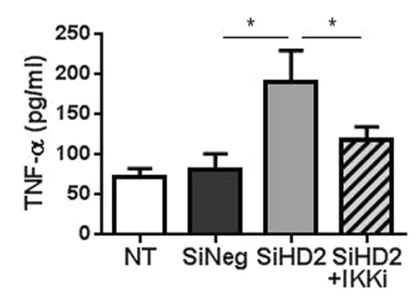

f
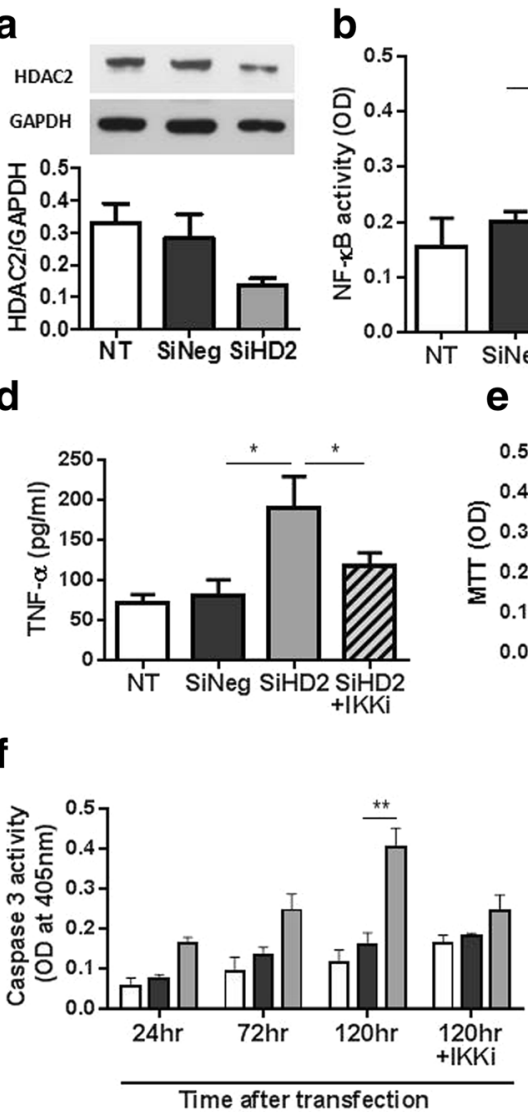

C Ac-p65 p65

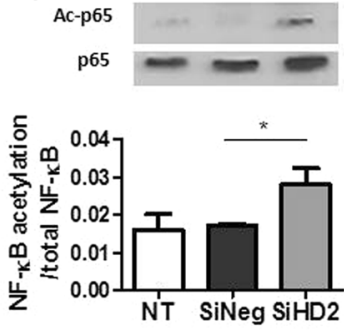

e

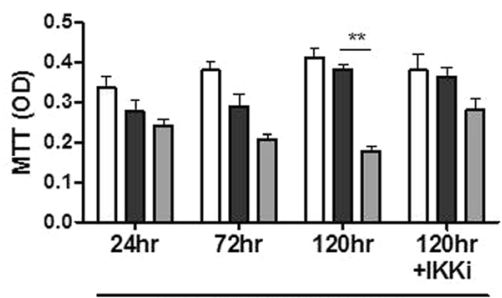

Time after transfection

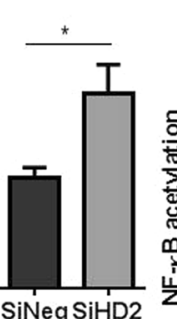

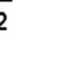




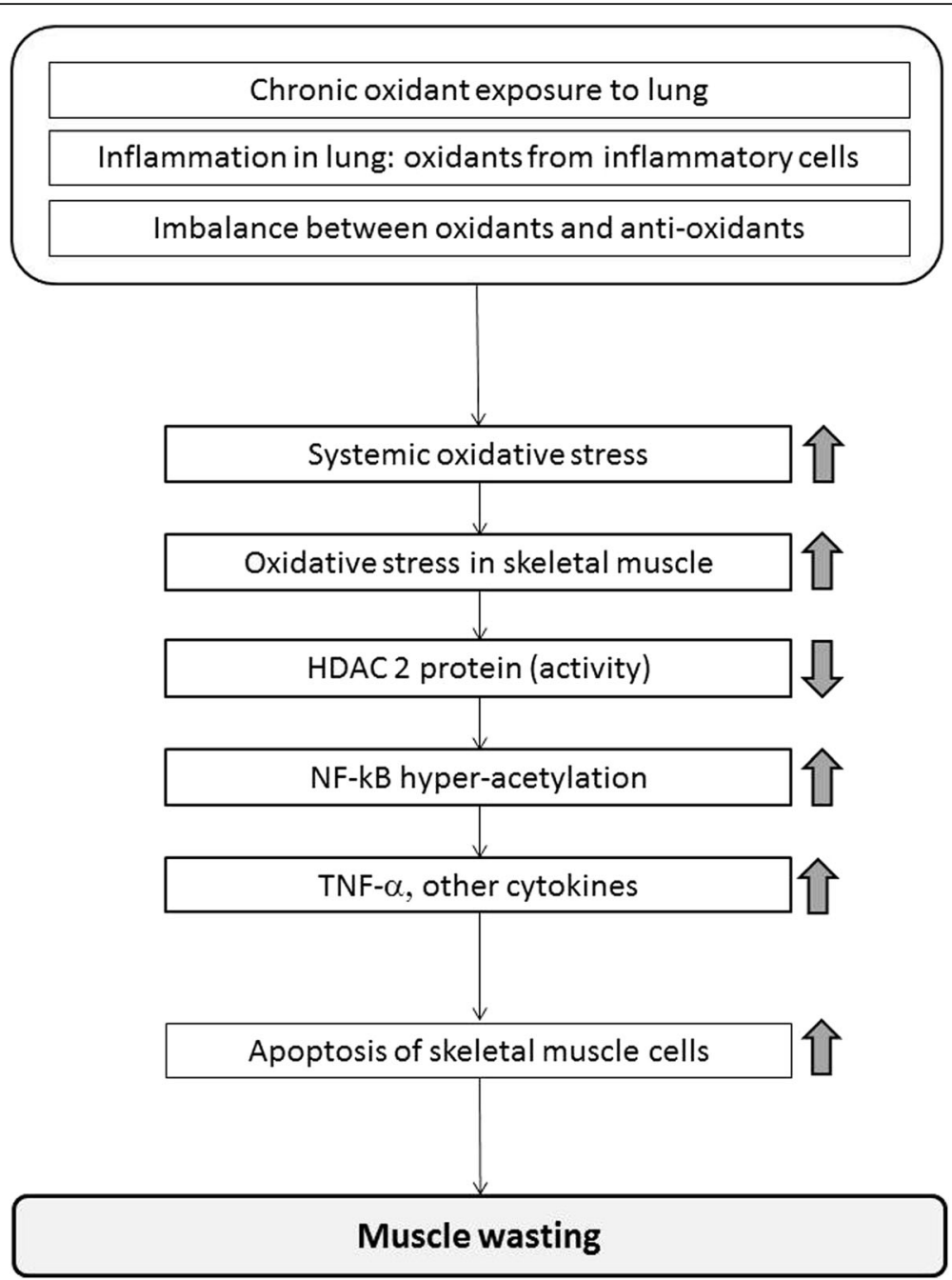

Fig. 4 A hypothetical scheme of how oxidative stress induces skeletal muscle dysfunction in COPD. HDAC2 reduction caused by oxidative stress in COPD (systemic and local) increase NF-kB activation and TNF-a expression resulting in muscle cell apoptosis and subsequent skeletal muscle dysfunction

reduction might induce apoptosis as HDAC2 knockdown induced apoptosis of skeletal muscle cells in our experiment. In fact, HDAC2 is reported to regulate skeletal muscle homeostasis in mice [41].

HDAC2 is known to be regulated differently in different stages of disease or in different tissue as follows; firstly, reduced enzyme activity can occur without any change of protein or mRNA expression, most likely due to post-translational modifications, such as nitration, oxidation and phosphorylation by oxidative stress. Secondly, HDAC2 protein reduction can occur without any change of transcription-mRNA due to degradation by the proteasome $[42,43]$. Thirdly, HDAC2 protein reduction can occur with reduced transcription, particularly seen in more severe COPD or in vitro after very high levels of oxidative stress exposure. In our data, the level of gene transcription HDAC2 (mRNA) was not decreased in COPD skeletal muscle while HDAC2 protein expression was decreased compared with controls. Therefore, it seems to be the second mechanism, with increased HDAC2 protein degradation, as a result of proteasome activation that predominates in skeletal muscle of COPD patients. Unfortunately, the samples from biopsy were too small to evaluate post-translational modification or the activity/molecule after immunoprecipitation. Any reduction in HDAC2 protein will necessarily also reduce its enzyme activity.

Collectively, our data and previously published findings suggest that oxidative stress, which derived originally from lung, then systemic and latterly in skeletal muscle, causes HDAC2 reduction. Then, the reduced HDAC2 leads an increase in NF-kB activation and TNF$\alpha$ expression resulting in muscle cell apoptosis and subsequent skeletal muscle dysfunction (Fig. 4).

However, there are some limitations in this study. Firstly, some measurements were not possible due to the 
small size of the biopsies, which were insufficient to analyse all desired parameters, such as HDAC2 activity, oxidative stress level and apoptosis and also a lack of serum samples to evaluate systemic oxidative stress. However, at least, apoptosis of skeletal muscle has previously been reported to be increased in COPD patients compared with controls $[44,45]$. Secondly, due to the small sample size, differences of HDAC2/5 in GOLD severity of the COPD patients, drug treatment and smoking status (current smokers or Ex-smokers), which might influence the results, was could not be evaluated. Thirdly, some clinical data including BODE score and fat free mass was not available. A study with larger sample size will be required to confirm our results. It would also be interesting to evaluate the effect of an HDAC activator, such as low dose oral theophylline, on skeletal muscle function in COPD patients with muscle weakness. HDAC5, as well as HDAC2, is reduced in peripheral lung of COPD patients [16]. In the current study, HDAC5 expression in COPD skeletal muscle was also found to be reduced compared with normal smokers, and was correlated with $\mathrm{FEV}_{1}$ and $\mathrm{FEV}_{1} / \mathrm{FVC}$, but not with $\mathrm{MVC}$ (Table 2). At least, from the current findings, HDAC2 reduction appears to be more important for the aetiology of muscle weakness in COPD than HDAC5 reduction. Further studies will be needed to explore the association between reduced HDAC5 and skeletal muscle dysfunction in COPD.

\section{Conclusions}

Reduction in HDAC2 in skeletal muscle appears to be involved in skeletal muscle dysfunction in COPD via acetylation and activation of NF- $\kappa B$. Restoration of HDAC2 expression might be an effective therapeutic target to improve skeletal muscle weakness in COPD patients.

\section{Additional file}

Additional file 1: Figure S1. HDACs mRNA expressions in skeletal muscle biopsies. (JPG $61 \mathrm{~kb}$ )

\footnotetext{
Abbreviation

COPD: Chronic obstructive pulmonary disease; GAPDH: Glyceraldehyde 3-phosphate dehydrogenase; GNB2L1: Guanine nucleotide-binding protein, beta-2-like 1; GOLD: The Global Initiative for Obstructive Lung Disease; HAT: Histone acetyltransferase; HDAC: Histone deacetylase; IKK: IkB kinase; MuRF1: Muscle RING-Finger Protein-1; MVC: Maximum voluntary contraction; NF-kB: Nuclear factor-kappa B; NrF2: Nuclear factor erythroid 2-related factor; PCR: Polymerase chain reaction; RNA: Ribonucleic acid; SDS/PAGE: Sodium dodecyl sulphate poly-acrylamide gel electrophoresis; siRNA: Short interfering RNA
}

Acknowledgements

Not applicable.
Funding

We acknowledge funding from a Wellcome Trust Programme Grant [076472/Z/05/Z] and this project was supported by the NIHR Respiratory Biomedical Research Unit at the Royal Brompton and Harefield NHS

Foundation Trust and Imperial College London.

\section{Availability of data and materials}

The datasets generated and/or analysed during the current study are available from the corresponding author on reasonable request.

\section{Authors' contributions}

MT, PJB, Kl contributed to the study concept and design, and the acquisition, analysis and interpretation of data. KA contributed to the acquisition and analysis of data. MIP, EBS \& SAS contributed to the recruitment of subjects and acquisition of clinical data. KH, MT, SAS, KI, MIP and PJB contributed to the drafting of the manuscript. All authors have approved the final version of the submitted manuscript.

\section{Competing interests}

The authors have reported no significant conflicts of interest exist with any companies/organizations whose products or services may be discussed in this article. The authors have reported relevant financial activities outside the submitted work as shown below. K.I is currently employed by Pumocide Ltd and conducted all experiments by the capacity of honorary contract with Imperial College. PJB has served on Scientific Advisory Boards of AstraZeneca, Boehringer-Ingelheim, Chiesi, Daiichi-Sankyo, GlaxoSmithKline, Novartis, Nycomed, Pfizer, Teva and UCB and has received research funding from Aquinox Pharmaceutiocals, AstraZeneca, Boehringer-Ingelheim, Chiesi, Daiichi-Sankyo, GlaxoSmithKline, Novartis, Nycomed, Pfizer and Prosonix.; MIP discloses receiving personal remuneration and/or remuneration to his institution for consultancy from GSK, AZ, Lilly, Pfizer, Novartis, Astellas, Regeneron and Biomarin. SAS discloses receiving personal remuneration and/or remuneration to his institution for consultancy from Astellas. PJB and MIP's contribution to this work was supported by the NIHR Respiratory Biomedical Research Unit at the Royal Brompton and Harefield NHS Foundation Trust and Imperial College, London UK who part fund his salary. The views expressed in this publication are those of the authors and not necessarily those of the NHS, The National Institute for Health Research or the Department of Health.

Consent for publication

Not applicable.

\section{Ethics approval and consent to participate}

Biopsies were obtained from two approved studies (Brompton, Harefield \&NHLI Ethics Committee, Ref 03-148) and (North London REC 3, Ref 06/ Q0410/54) and written informed consent was obtained from all subjects.

\section{Publisher's Note}

Springer Nature remains neutral with regard to jurisdictional claims in published maps and institutional affiliations.

\section{Author details}

${ }^{1}$ Airway Disease Section, National Heart and Lung Institute, Imperial College, Dovehouse Street, London SW3 6LY, UK. ${ }^{2}$ NIHR Respiratory Biomedical Research Unit at the Royal Brompton and Harefield Foundation Trust \& Imperial College, London, UK. ${ }^{3}$ Department of Laboratory Medicine, Dokkyo Medical University Koshigaya Hospital, 2-1-50 Minami-Koshigaya, Koshigaya-City, Saitama 343-8555, Japan. ${ }^{4}$ Molecular Medicine, National Heart and Lung institute, Imperial College London, London SW7 2AZ, UK.

Received: 13 April 2017 Accepted: 16 May 2017

Published online: 19 May 2017

References

1. Lopez AD, Murray CC. The global burden of disease, 1990-2020. Nat Med. 1998:4:1241-43.

2. Bernard S, LeBlanc P, Whittom F, Carrier G, Jobin J, Belleau R, Maltais F. Peripheral muscle weakness in patients with chronic obstructive pulmonary disease. Am J Respir Crit Care Med. 1998;158:629-34. 
3. Man WD, Soliman MG, Nikoletou D, Harris ML, Rafferty GF, Mustfa N, Polkey MI, Moxham J. Non-volitional assessment of skeletal muscle strength in patients with chronic obstructive pulmonary disease. Thorax. 2003:58:665-69.

4. Man WD, Hopkinson NS, Harraf F, Nikoletou D, Polkey MI, Moxham J. Abdominal muscle and quadriceps strength in chronic obstructive pulmonary disease. Thorax. 2005;60:718-22.

5. Serres I, Gautier V, Varray A, Prefaut C. Impaired skeletal muscle endurance related to physical inactivity and altered lung function in COPD patients. Chest. 1998;113:900-05.

6. Allaire J, Maltais F, Doyon JF, Noel M, LeBlanc P, Carrier G, Simard C, Jobin J. Peripheral muscle endurance and the oxidative profile of the quadriceps in patients with COPD. Thorax. 2004;59:673-78.

7. Seymour JM, Spruit MA, Hopkinson NS, Natanek SA, Man WD, Jackson A Gosker HR, Schols AM, Moxham J, Polkey MI, Wouters EF. The prevalence of quadriceps weakness in COPD and the relationship with disease severity. Eur Respir J. 2010;36:81-8.

8. Swallow EB, Reyes D, Hopkinson NS, Man WD, Porcher R, Cetti EJ, Moore AJ, Moxham J, Polkey MI. Quadriceps strength predicts mortality in patients with moderate to severe chronic obstructive pulmonary disease. Thorax. 2007;62:115-20.

9. Man WD, Kemp P, Moxham J, Polkey MI. Skeletal muscle dysfunction in COPD: clinical and laboratory observations. Clin Sci (Lond). 2009;117:251-64.

10. Agusti A, Morla M, Sauleda J, Saus C, Busquets X. NF-kappaB activation and iNOS upregulation in skeletal muscle of patients with COPD and low body weight. Thorax. 2004;59:483-87.

11. Maltais F, Decramer M, Casaburi R, Barreiro E, Burelle $Y$, Debigare $R$, Dekhuijzen PN, Franssen F, Gayan-Ramirez G, Gea J, Gosker HR, Gosselink R, Hayot M, Hussain SN, Janssens W, Polkey MI, Roca J, Saey D, Schols AM, Spruit MA, Steiner M, Taivassalo T, Troosters T, Vogiatzis I, Wagner PD. An official American Thoracic Society/European Respiratory Society statement: update on limb muscle dysfunction in chronic obstructive pulmonary disease. Am J Respir Crit Care Med. 2014;189:e15-62.

12. Guo Y, Gosker HR, Schols AM, Kapchinsky S, Bourbeau J, Sandri M, Jagoe RT, Debigare R, Maltais F, Taivassalo T, Hussain SN. Autophagy in locomotor muscles of patients with chronic obstructive pulmonary disease. Am J Respir Crit Care Med. 2013;188:1313-20.

13. Puig-Vilanova E, Ausin P, Martinez-Llorens J, Gea J, Barreiro E. Do epigenetic events take place in the vastus lateralis of patients with mild chronic obstructive pulmonary disease? PLoS One. 2014;9:e102296.

14. Puig-Vilanova E, Martinez-Llorens J, Ausin P, Roca J, Gea J, Barreiro E. Quadriceps muscle weakness and atrophy are associated with a differential epigenetic profile in advanced COPD. Clin Sci (Lond). 2015;128:905-21.

15. de Ruijter AJ, van Gennip AH, Caron HN, Kemp S, van Kuilenburg AB. Histone deacetylases (HDACs): characterization of the classical HDAC family. Biochem J. 2003:370:737-49.

16. Ito K, Ito M, Elliott WM, Cosio B, Caramori G, Kon OM, Barczyk A, Hayashi S, Adcock IM, Hogg JC, Barnes PJ. Decreased histone deacetylase activity in chronic obstructive pulmonary disease. N Engl J Med. 2005;352:1967-76.

17. Ito K, Charron CE, Adcock IM. Impact of protein acetylation in inflammatory lung diseases. Pharmacol Ther. 2007;116:249-65.

18. Rabe KF, Hurd S, Anzueto A, Barnes PJ, Buist SA, Calverley P, Fukuchi Y, Jenkins C, Rodriguez-Roisin R, van Weel C, Zielinski J. Global strategy for the diagnosis, management, and prevention of chronic obstructive pulmonary disease: GOLD executive summary. Am J Respir Crit Care Med. 2007;176:532-55.

19. Bergstrom J. Percutaneous needle biopsy of skeletal muscle in physiological and clinical research. Scand J Clin Lab Invest. 1975;35:609-16.

20. Cosio BG, Tsaprouni L, Ito K, Jazrawi E, Adcock IM, Barnes PJ. Theophylline restores histone deacetylase activity and steroid responses in COPD macrophages. J Exp Med. 2004;200:689-95.

21. Ito K, Lim S, Caramori G, Chung KF, Barnes PJ, Adcock IM. Cigarette smoking reduces histone deacetylase 2 expression, enhances cytokine expression, and inhibits glucocorticoid actions in alveolar macrophages. FASEB J. 2001;15:1110-12.

22. Ito K, Hanazawa T, Tomita K, Barnes PJ, Adcock IM. Oxidative stress reduces histone deacetylase 2 activity and enhances IL-8 gene expression: role of tyrosine nitration. Biochem Biophys Res Commun. 2004;315:240-45.

23. Barreiro E, Gea J, Corominas JM, Hussain SN. Nitric oxide synthases and protein oxidation in the quadriceps femoris of patients with chronic obstructive pulmonary disease. Am J Respir Cell Mol Biol. 2003;29:771-78.
24. Barreiro E, Schols AM, Polkey MI, Galdiz JB, Gosker HR, Swallow EB, Coronell C, Gea J. Cytokine profile in quadriceps muscles of patients with severe COPD. Thorax. 2008;63:100-7.

25. Barreiro E. Protein carbonylation and muscle function in COPD and other conditions. Mass Spectrom Rev. 2014;33:219-36.

26. Koechlin C, Couillard A, Simar D, Cristol JP, Bellet H, Hayot M, Prefaut C. Does oxidative stress alter quadriceps endurance in chronic obstructive pulmonary disease? Am J Respir Crit Care Med. 2004;169:1022-27.

27. Rossman MJ, Garten RS, Groot HJ, Reese V, Zhao J, Amann M, Richardson RS. Ascorbate infusion increases skeletal muscle fatigue resistance in patients with chronic obstructive pulmonary disease. Am J Physiol Regul Integr Comp Physiol. 2013;305:R1163-70.

28. Mercado N, Thimmulappa R, Thomas CM, Fenwick PS, Chana KK, Donnelly LE, Biswal S, Ito K, Barnes PJ. Decreased histone deacetylase 2 impairs Nrf2 activation by oxidative stress. Biochem Biophys Res Commun. 2011;406:292-98.

29. Enesa K, Ito K, Luong IA, Thorbjornsen I, Phua C, To Y, Dean J, Haskard DO, Boyle J, Adcock I, Evans PC. Hydrogen peroxide prolongs nuclear localization of NF-kappaB in activated cells by suppressing negative regulatory mechanisms. JBiolChem. 2008;283:18582-90.

30. Schreck R, Rieber P, Baeuerle PA. Reactive oxygen intermediates as apparently widely used messengers in the activation of the NF-kappa B transcription factor and HIV-1. EMBO J. 1991:10:2247-58.

31. Chen L, Fischle W, Verdin E, Greene WC. Duration of nuclear NF-kappaB action regulated by reversible acetylation. Science. 2001;293:1653-57.

32. Rothgiesser KM, Erener S, Waibel S, Luscher B, Hottiger MO. SIRT2 regulates NF-kappaB dependent gene expression through deacetylation of p65 Lys310. J Cell Sci. 2010;123:4251-58.

33. Yeung F, Hoberg JE, Ramsey CS, Keller MD, Jones DR, Frye RA, Mayo MW. Modulation of NF-kappaB-dependent transcription and cell survival by the SIRT1 deacetylase. EMBO J. 2004;23:2369-80.

34. Cai D, Frantz JD, Tawa Jr NE, Melendez PA, Oh BC, Lidov HG, Hasselgren PO, Frontera WR, Lee J, Glass DJ, Shoelson SE. IKKbeta/NF-kappaB activation causes severe muscle wasting in mice. Cell. 2004;119:285-98.

35. Doucet M, Russell AP, Leger B, Debigare R, Joanisse DR, Caron MA, LeBlanc $P$, Maltais F. Muscle atrophy and hypertrophy signaling in patients with chronic obstructive pulmonary disease. Am J Respir Crit Care Med. 2007;176:261-69.

36. Plant PJ, Brooks D, Faughnan M, Bayley T, Bain J, Singer L, Correa J, Pearce $D$, Binnie $M$, Batt J. Cellular markers of muscle atrophy in chronic obstructive pulmonary disease. Am J Respir Cell Mol Biol. 2010;42:461-71.

37. Natanek SA, Riddoch-Contreras J, Marsh GS, Hopkinson NS, Moxham J, Man WD, Kemp PR, Polkey MI. MuRF-1 and atrogin-1 protein expression and quadriceps fiber size and muscle mass in stable patients with COPD. COPD. 2013;10:618-24

38. Dupre-Aucouturier S, Castells J, Freyssenet D, Desplanches D. Trichostatin A, a histone deacetylase inhibitor, modulates unloaded-induced skeletal muscle atrophy. J Appl Physiol (1985). 2015;119:342-51.

39. Tracey KJ, Cerami A. Tumor necrosis factor, other cytokines and disease. Annu Rev Cell Biol. 1993;9:317-43.

40. Adams V, Spate U, Krankel N, Schulze PC, Linke A, Schuler G, Hambrecht R. Nuclear factor-kappa B activation in skeletal muscle of patients with chronic heart failure: correlation with the expression of inducible nitric oxide synthase. Eur J Cardiovasc Prev Rehabil. 2003;10:273-77.

41. Moresi V, Carrer M, Grueter CE, Rifki OF, Shelton JM, Richardson JA, Bassel-Duby R, Olson EN. Histone deacetylases 1 and 2 regulate autophagy flux and skeletal muscle homeostasis in mice. Proc Natl Acad Sci U S A. 2012;109:1649-54.

42. Osoata GO, Yamamura S, Ito M, Vuppusetty C, Adcock IM, Barnes PJ, Ito K. Nitration of distinct tyrosine residues causes inactivation of histone deacetylase 2. Biochem Biophys Res Commun. 2009;384:366-71.

43. Adenuga D, Yao H, March TH, Seagrave J, Rahman I. Histone deacetylase 2 is phosphorylated, ubiquitinated, and degraded by cigarette smoke. Am J Respir Cell Mol Biol. 2009:40:464-73.

44. Agusti AG, Sauleda J, Miralles C, Gomez C, Togores B, Sala E, Batle S, Busquets X. Skeletal muscle apoptosis and weight loss in chronic obstructive pulmonary disease. Am J Respir Crit Care Med. 2002;166:485-9.

45. Barreiro E, Ferrer D, Sanchez F, Minguella J, Marin-Corral J, Martinez-Llorens J, Lloreta J, Gea J. Inflammatory cells and apoptosis in respiratory and limb muscles of patients with COPD. J Appl Physiol (Bethesda, Md : 1985). 2011;111:808-17. 